\title{
Enzymatic, urease-mediated mineralization of gellan gum hydrogel with calcium carbonate, magnesium-enriched calcium carbonate and magnesium carbonate for bone regeneration applications
}

Douglas, Timothy; Lapa, Agata; Samal, Sangram K.; Declercq, Heidi A.; Schaubroeck, David; Mendes, Ana Carina Loureiro; Van Der Voort, Pascal ; Dokupil, Agnieszka; De Schamphelaere, Karel; Chronakis, loannis S.

Total number of authors:

12

Link to article, DOI:

10.3389/conf.FBIOE.2016.01.00370

Publication date:

2016

Document Version

Publisher's PDF, also known as Version of record

Link back to DTU Orbit

Citation (APA):

Douglas, T., Lapa, A., Samal, S. K., Declercq, H. A., Schaubroeck, D., Mendes, A. C. L., Van Der Voort, P., Dokupil, A., De Schamphelaere, K., Chronakis, I. S., Pamula, E., \& Skirtach, A. G. (2016). Enzymatic, ureasemediated mineralization of gellan gum hydrogel with calcium carbonate, magnesium-enriched calcium carbonate and magnesium carbonate for bone regeneration applications. Abstract from 10th World Biomaterials Congress, Montreal, Quebec, Canada. https://doi.org/10.3389/conf.FBIOE.2016.01.00370

\section{General rights}

Copyright and moral rights for the publications made accessible in the public portal are retained by the authors and/or other copyright owners and it is a condition of accessing publications that users recognise and abide by the legal requirements associated with these rights.

- Users may download and print one copy of any publication from the public portal for the purpose of private study or research.

- You may not further distribute the material or use it for any profit-making activity or commercial gain

- You may freely distribute the URL identifying the publication in the public portal 


\title{
Enzymatic, urease-mediated mineralization of gellan gum hydrogel with calcium carbonate, magnesium-enriched calcium carbonate and magnesium carbonate for bone regeneration applications
}

\author{
Pamula ${ }^{2}$ and Andre G. Skirtach ${ }^{1,4}$ \\ Ghent University, Molecular Biotechnology, Belgium \\ 2 AGH University of Science and Technology, Biomaterials, Poland \\ 3 Ghent University, General Biochemistry and Physical Pharmacy, Belgium \\ Ghent University, Centre for Nano- and Biophotonics, , Belgium \\ Ghent University, Basic Medical Science, Belgium \\ imec and Ghent University, Center for Microsystems Technology (CMST), Belgium \\ Technical University of Denmark (DTU), Nano-BioScience Research Group, Denmark \\ Ghent University, Inorganic Chemistry, Belgium \\ Institute for Chemical Processing of Coal, Poland \\ 10 Ghent University, Laboratory for Environmental and Aquatic Ecology, Environmental Toxicology Unit (GhEnToxLab), Belgium
}

Timothy Douglas ${ }^{1}$, Agata Lapa ${ }^{2}$, Sangram K. Samal ${ }^{3}, 4$, Heidi A. Declercq ${ }^{5}$, David Schaubroeck ${ }^{6}$, Ana C. Mendes ${ }^{7}$, Pascal Van Der Voort ${ }^{8}$, Agnieszka Dokupil ${ }^{9}$, Agnieszka Plis ${ }^{9}$, Karel De Schamphelaere ${ }^{10}$, loannis S. Chronakis ${ }^{7}$, Elzbieta

Introduction: Mineralization of hydrogel biomaterials is considered desirable to improve their suitability as materials for bone regeneration ${ }^{[1],[2]}$. Hydrogels have been most commonly mineralized with calcium phosphate (CaP), but hydrogel-CaCO3 composites have received less attention. Magnesium (Mg) has been added to CaP to stimulate cell adhesion and proliferation and bone regeneration in vivo, but its effect as a component of carbonate-based biomaterials remains uninvestigated. In this study, gellan gum (GG) hydrogels were mineralized enzymatically with (CaCO3), Mg-enriched CaCO3 and magnesium carbonate to generate composite biomaterials for bone regeneration. GG is an inexpensive, biotechnologically produced anionic polysaccharide, from which hydrogels for cartilage regeneration have been formed by crosslinking with divalent ions ${ }^{[3]}$.

Methods: GG hydrogels were loaded with the enzyme urease by incubation in $5 \%$ (w/v) urease solution and mineralized for 5 days in five different media denoted as UA, UB, UC, UD and UE, which contained urea ( $0.17 \mathrm{M})$ and different concentrations of CaCl2 and MgCl2 (270:0, 202.5:67.5, 135:135, 67.5:202.5 and 0:250, respectively (mmol dm-3)). Discs were autoclaved and subjected to physiochemical, mechanical and cell biological characterization.

Results: FTIR, SEM, TGA and XRD analysis revealed that increasing magnesium concentration decreased mineral crystallinity. At low magnesium concentrations calcite was formed, while at higher concentrations magnesian calcite was formed. Hydromagnesite formed at high magnesium concentration in the absence of calcium. Amount of mineral formed and compressive strength decreased with increasing magnesium concentration in the mineralization medium. ICP analysis revealed that Ca:Mg elemental ratio in the mineral formed was higher than in the respective mineralization media. Mineralization of hydrogels promoted adhesion and growth of osteoblast-like cells, which were supported best on mineralized hydrogels containing no or little magnesium. Hydrogels mineralized with hydromagnesite displayed higher cytotoxicity.

Discussion: Enzymatic mineralization of GG hydrogels with CaCO3 in the form of calcite successfully reinforced hydrogels and promoted osteoblast-like cell adhesion and growth, but Mg enrichment had no positive effect. This is in contrast with other studies reporting that incorporation of Mg into GG mineralized with CaP promotes cell adhesion and proliferation ${ }^{[4]}$.

Conclusion: Sample groups UA and UB seem to be the most promising due to the superior amount of mineral formed and cell adhesion and proliferation.

FWO, Belgium; BOF (Bijzonder Onzderzoeksfonds) of Ghent University, Belgium

References:

[1] Gkioni K, et al. Tissue Eng Part B Rev 2010;16(6):577-85

[2] Suzawa Y, et al. J Biomed Mater Res A 2010;93(3):965-75

[3] Oliveira JT, et al. J Biomed Mater Res A 2010;93(3):852-63.

[4] Douglas TEL, et al. J Tissue Eng Regen Med 2014

Keywords: Hydrogel, enzyme, Biomimetic, composite Conference: 10th World Biomaterials Congress, Montréal, Canada, 17 May - 22 May, 2016. Presentation Type: Poster Topic: Composites: polymeric, ceramic and metallic

Citation: Douglas T, Lapa A, Samal SK, Declercq HA, Schaubroeck D, Mendes AC, Van Der Voort P, Dokupil A, Plis A, De Schamphelaere K, Chronakis IS, Pamula E and Skirtach AG (2016). Enzymatic, urease-mediated mineralization of gellan gum hydrogel with calcium carbonate, magnesium-enriched calcium carbonate and magnesium carbonate for bone regeneration applications. Front. Bioeng. Biotechnol. Conference Abstract: 10th World Biomaterials Congress. doi: 10.3389/ conf. FBIOE. 2016.01.00370

Received: 27 Mar 2016; Published Online: 30 Mar 2016. 
11/10/2016 Frontiers | Enzymatic, urease-mediated mineralization of gellan gum hydrogel with calcium carbonate, magnesium-enriched calcium carbonate an...

(c) 2007 - 2016 Frontiers Media S. A. All Rights Reserved 